\title{
ESCENARIOS DE PODER. EVOLUCIÓN DE LA ARQUITECTURA TEATRAL EN LA ESPAÑA DEL SIGLO XVII: DE LA CIRCUNSTANCIA A LA PERMANENCIA EN EL COLISEO DEL BUEN RETIRO
}

\author{
Esther Merino \\ (Universidad Complutense de Madrid) \\ emerino@ucm.es
}

\section{RESUMEN}

Hasta la construcción del Coliseo del Palacio de El Buen Retiro no hubo un emplazamiento o sede permanente, para espectáculos y representaciones teatrales en la España de los Austrias. Por eso mismo se fueron trasladando las distintas celebraciones cortesanas según se iban desplazando los monarcas por las diferentes residencias palatinas de los diferentes Sitios Reales, que circunvalaban o rodeaban la capital. Se propone un recorrido por las primeras muestras de la influencia italiana hasta la configuración de la arquitectura teatral cortesana en España, a lo largo del siglo XVII.

PALABRAS CLAVE: Arquitectura Teatral Cortesana, Coliseo del Palacio del Buen Retiro, siglo XVII.

\section{POWER STAGES. EVOLUTION OF THEATRICAL ARCHITECTURE IN 17TH CENTURY SPAIN: FROM CIRCUMSTANCE TO PERMANENCE IN THE BUEN RETIRO COLISEUM}

\begin{abstract}
Until the construction of the Coliseum of the Palacio de El Buen Retiro there was no permanent location or headquarters for shows and theatrical representations in the Spain of the Habsburgs. For this reason, the different courts celebrations were transferred as the monarchs moved through the different palatine residences of the different Royal Sites, which circled or surrounded the capital. It is proposed a journey through the first samples of Italian influence to the configuration of court theatrical architecture in Spain, throughout the seventeenth century.
\end{abstract}

KEY WORDS: Court theatrical architecture, Coliseum of the Palacio de El Buen Retiro, Seventeenth century. 


\section{Aproximaciones al teatro cortesano de influencia italiana. La Gloria de Niquea. Aranjuez 1622}

En abril de 1622 se celebraba el cumpleaños del Felipe IV y también se quería conmemorar, de paso, el segundo año de reinado de un monarca que sucedía a su padre apenas con 16 años, para consolidar su figura, en el marco de una corriente general que se alegraba del cambio de régimen y del final que suponían, con la muerte de Felipe III, los privilegios casi omnímodos del Duque de Lerma ${ }^{1}$ y de Uceda, respectivamente.

En ese ambiente crítico contra el gobierno de los «validos» había participado muy activamente el famoso Conde de Villamediana, uno de los personajes más fascinantes de la época, noble, escritor y libertino o vividor apasionado a partes iguales, que tenía fascinada a la corte madrileña. Fue Juan de Tassis (1582-1622) quien escribió La Gloria de Niquea, uno de los dos textos que se escenificaron en el Jardín de la Isla, en el Palacio de Aranjuez para las celebraciones en honor del nuevo reinado, de cuyo montaje se pueden encontrar noticias en las Relación de Antonio Hurtado de Mendoza, así como en el interesantísimo Memorial del pintor Urbano de Baraona², quien fuera, además pintor de una buena parte del aparato efímero de montaje, junto a Gaspar Tarsín, mencionado específicamente como «pintor del aparato de la comedia», entre

1 Ya durante el reinado de Felipe III se fue haciendo ostensible la necesidad de ubicar específicamente los espectáculos cortesanos. Señala Teresa Ferrer Valls que puede entenderse como precedentes excepcionales la «Sala de Saraos» (habilitadas para bailes y danzas cortesanas) que se construyó de fábrica, en el Palacio de Valladolid -donde estuvo desplazada temporalmente la corte regiay donde se celebraron algunos de los actos conmemorativos con ocasión del nacimiento del heredero, futuro rey Felipe IV, el 16 de junio de 1605. Al parecer, dicha sala amplió sus funciones para albergar la escenificación de cuadros teatrales más complejos. Edificada por Francisco de Mora, contó con decoraciones pictóricas de Vicente Carducho en un espacio que rondaba casi los trece metros de altura, que indicaban, quizás, una mayor capacidad para albergar maquinaria de «vuelos», a la manera de lo que se estaba imponiendo en la escenografía italiana. Hubo otros ejemplos previos a la arquitectura teatral de carácter permanente, de lo que Teresa Ferrer denomina «teatros circunstanciales» o efímeros y descubiertos, compuestos a manera de tablados como plataformas donde se integraba todo el edificio y espacios relacionados con la puesta en escena, en un solo nivel, en el que también se disponía la decoración escenográfica, apenas separada en una zona acotada y cubiertas de toldos a manera de cerramiento. Así puede documentarse para la representación en el parque de Lerma, El premio de la hermosura (1614) de Lope de Vega y El caballero del sol (1617) de Luis Vélez de Guevara. Lo cierto es que de tales relaciones o descripciones parece deducirse una mayor semejanza arquitectónica en líneas generales con los corrales de comedias habituales de la geografía urbana popular, a los que los monarcas eran aficionados, pero ya se ven adaptaciones parciales, para trasladar al ámbito cortesano la celebración lúdica, como cauce de transmisión de la propaganda áulica propia de las monarquías absolutas en ciernes, razón por la cual solía hacerse hincapié en el uso de la «perfecta perspectiva» en las composiciones decorativas, a la manera de los usos y costumbres del arte italiano aplicado a la escenografía teatral, junto a la amplificación del espacio interior para albergar maquinaria y movimiento en el escenario. Teresa Ferrer Valls, "Teatros cortesanos anteriores a la construcción del Coliseo del Buen Retiro", Quaderns de Filología. Estudis literans, Edición en homenaje a la profesora Amelia García-Valdecasas I (1995), 355-372.

${ }^{2}$ Que aporta Teresa Chaves Montoya en La Gloria de Niquea. Una invención en la Corte de Felipe IV, Colección Riada, Estudios sobre Aranjuez 2 (Aranjuez: Editorial Doce Calles, 1991). Memoria de Urbano de Baraona en Cuentas del Capitán Julio Cesar Fontana, Valladolid AGS. 
cuyas funciones estaba la de «pintar, platear, dorar los elementos escenográficos, estables y móviles». ${ }^{3}$

No es ninguna casualidad que en uno de los primeros párrafos de la obra se haga una correspondencia entre el cuerpo arquitectónico de la estructura teatral improvisada para cobijar la escenificación mitológica y «los Romanos Coliseos a imitación de los Antiguos», dado que a continuación se menciona a Vitruvio o al escultor de época helenística, Lisipo y tanto el autor del texto, el Conde de Villamediana, como el arquitecto encargado de su montaje, Giulio Cesare Fontana, habían tenido una más que amplia formación humanística. Fontana era hijo de Domenico, Ingeniero Mayor del Reino de Nápoles (1592-1607), a quien sucedió en el cargo apenas un mes después de su muerte y del que se sabe que recibía un sueldo de 61 ducados mensuales antes de trasladarse a España en 1616, para el diseño del aparato efímero y la supervisión de las obras necesarias para la ubicación de la Fiesta de Aranjuez y donde, al parecer, «se hizo apreciar por su capacidad técnica y de gestión de todos los aspectos» ${ }^{4}$ para la escenificación del espectáculo, por el que cobró un estipendio de 500 ducados.

No es el propósito ahondar mucho más en la evidente polisemia de la obra para glorificar al nuevo monarca, en la que se mezclan o interactúan modelos de referencia de la literatura artúrica, los libros de caballerías, que reflejaban el mundo del torneo medieval ${ }^{5}$, reconvertidos en fábulas mitológicas, mascaradas bajo el apelativo de «comedia», aunque no lo fueran como tal (porque retoman el concepto vitruviano que se consideraba el más adecuado para la representación en el marco urbano de la nueva escena moderna, la città efimera ${ }^{6}$ que rememora Fagiolo en uno de sus títulos más famosos). La interacción de todos ellos evolucionaría hacia lo que terminaría convirtiéndose en la dramaturgia barroca, definida en un nuevo género literario de los $\operatorname{libretos}^{7}$, o textos recopilatorios de texto propiamente e información sobre escenografía y maquinaria necesaria para su puesta en escena, como base de la ópera.

\footnotetext{
${ }^{3}$ Chaves Montoya, La Gloria de Niquea. Una invención en la Corte de Felipe IV, 59.

${ }^{4}$ Marcello Fagiolo y Giuseppe Bonacorso Bonacorso, Studi sui Fontana. Una dinastía di architetti ticinesi a Roma tra Manierismo e Barocco (Roma: Gangemi Editore, Centro di Studi sulla Cultura e l'immagine di Roma, Ministero per I Beni e le Attività Culturali, 2016), 119. No deja de ser interesante que, al igual que la actuación de Giulio Cesare en Aranjuez se considere inauguración del género dramático escenográfico de influencia italiana en España y que otro Fontana, Carlo «architetto teatrale» (16381714) esté relacionado, precisamente con la orientación de esa misma configuración escénica barroca, con el montaje a su vez, del que se ocupó por orden de otro noble español, el Marqués de Cogolludo, para celebrar el matrimonio del rey Carlos II, con María Luisa de Orleans, en el Palacio Farnese de Roma, a finales de siglo (1688), conocido como La caduta del regno delle Amazone.

${ }^{5}$ Esther Merino, "De la guerra al espectáculo cortesano: El arte efímero en el torneo", en El reino de la ilusión. Breve historia y tipos de espectáculo. El arte efimero y los orígenes de la escenografía, Monografías de Arquitectura 01 (2005), 15-44. Y María del Rosario Aguilar Perdomo, "La disposición escénica: algunas arquitecturas efímeras de los libros de caballerías españoles", Revista Destiempos 23 (diciembre 2009-enero 2010).

${ }^{6}$ Marcello Fagiolo, La Città effimera e l'universo artificiale del giardino: la Firenze dei Medici e l'Italia del '500.

${ }^{7}$ Lorenzo Bianconi, "Il libretto d'opera", en Il contributo italiano alla storia del pensiero (Roma: Istituto dello Enciclopedia Italiana Fondata da Giovanni Treccani, 2018), 187-204.
} 
En este caso, en la aproximación a la configuración de una arquitectura teatral hispana, interesa ahondar en la descripción de lo que fue, aún en Aranjuez, una estructura efímera, ideada para ser desmontada cuando acabaran los fastos, que, en el texto de Villamediana (fuera o no redactado por amanuense) parece reflejar el «espíritu» del ideario de Fontana y de su transferencia de la experiencia italiana, mencionándose en varias ocasiones el término «anfiteatro», para definir, cuando menos, el contorno o perímetro de la planta de la improvisada estructura, para la que se construyeron, entre catorce y diecisiete arquerías, de fondo, asentadas sobre columnas de orden dórico. En la reconstrucción que ilustra el texto de Chaves, se pueden ver las similitudes con otra restitución que hiciera Arnaldo Bruschi en el texto de Fabrizio Cruciani ${ }^{8}$, en este caso del perfil del conocido como Teatro del Campidoglio, o sea de la estructura creada por Baldasarre Peruzzi para las celebraciones romanas de 1513, que suponían la "entronización” de un Pontífice de la familia de los Medici en Roma y donde se ubicó el montaje, como pieza principal, de La Calandria del cardenal Bibiena.

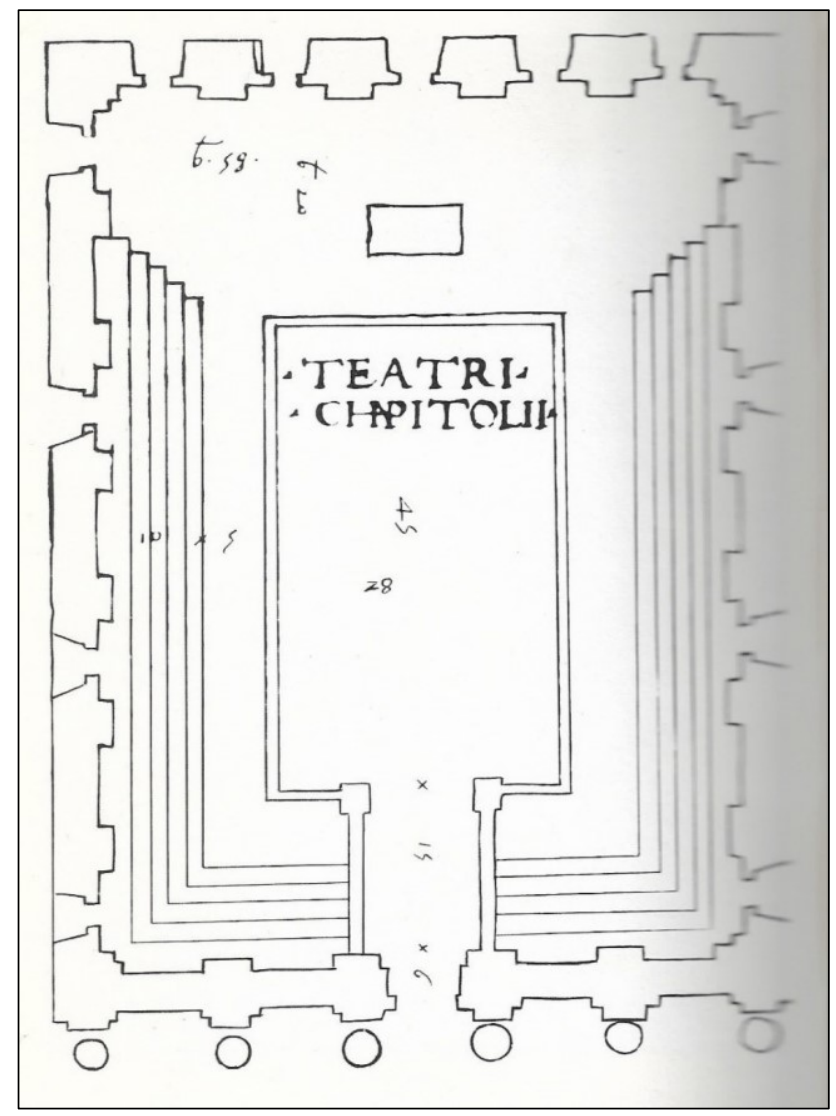

Fig. 1. Reconstrucción del Teatro del Campidoglio Roma.

${ }^{8}$ Fabrizio Cruciani, Il teatro del Campidoglio e le feste romane del 1513 (Milán: Il Polifilo, 1968). 
Sobre las arquerías, intentando emular la estratigrafía característica de los órdenes clásicos, que igualmente preconizaba el tratado de Vitruvio, se levantaba una franja transversal, con función unificadora, una cornisa, compuesto su friso de triglifos y metopas sustituidas por follaje dorado y superpuesta una galería de 150 balaustres, todo lo cual, incluyendo varias esferas de cristal en las que reflejarían los destellos de las muchas luminarias colocadas por todo el recinto, se cubrió por un inmenso toldo simulando un cielo estrellado. Además de abundante decoración escultórica de tamaño más modesto, en el centro del escenario aparecían dos colosos simulando ser figuras de bronce (realizadas con barro de Olleros y lienzo) representando los personajes de Mercurio (embajador de los dioses y de las noticias) y Marte, máxima divinidad de la guerra, ambas dos imágenes aludidas con fundado sentido metafórico y simbólico, realizadas por Juan Antonio Cerón o Ceroni.

«Más esfera que palacio [...] más milagro que edificio» ${ }^{9}$, al margen del entramado o andamiaje puramente estructural, es ostensible que la funcionalidad de algunos de los espacios, como la colocación de los músicos y coros de la Capilla Real, emplazados en una galería sobre los arcos, y la composición de la decoración escenográfica, respondía ya conceptualmente al ideario del entretenimiento lúdico ensayado y codificado en Italia, desde mediados del siglo XVI, a través de las creaciones del artista profesional, el escenógrafo, en el que se focalizaron la dirección y el diseño de todos los elementos que componían el montaje efímero de la Fiesta al servicio de la propaganda áulica, fundamentalmente en Florencia, con Giorgio Vasari y Bernardo Buontalenti después.

En este sentido, el planteamiento de la estructura y los elementos escenográficos de Aranjuez recuerdan a la puesta en escena de los Intermezzi de 1589, de La Pellegrina, donde terminaron de codificarse los aspectos sustanciales del ideario metafórico del «buen gobierno», los cuales, desde entonces fueron indisolublemente asociados por analogía a la representación del mejor ejercicio de las funciones del gobierno, en principio creado para los Medici, pero sin solución de continuidad convertido en fórmula prototípica, emblema iconográfico ${ }^{10}$, del que se apropiaron los monarcas del Absolutismo barroco. Se trata de la alegoría de los cuatro elementos, que se remonta a los principios esbozados por Tales de Mileto, cuando afirmaba que el origen de la vida se encontraba en la confluencia de las sustancias básicas en la naturaleza, pero principalmente el agua, de manera que a partir de las decoraciones creadas para los interludios musicales entreactos de la representación teatral y para que no hubiera cesura ni interrupción en la atención de los espectadores, se ideó un género musical específicamente. Así, Buontalenti -rememorando la experiencia florentina en divertimentos relacionados con la música asociada a Orfeo, como santo protector de

\footnotetext{
${ }^{9}$ Así describía Antonio Hurtado de Mendoza el espacio escénico para la representación de otro de sus textos, Querer por solo querer, comedia que representaron las señoras meninas (1623).

${ }^{10}$ Como antaño lo fue en las artes plásticas, la representación de la nave de la famosa historia de los Argonautas, en la que Jasón, además de astucia, demostró criterio para guiar el barco que terminó conduciendo a la victoriosa empresa por la que se consiguió el mítico distintivo del Vellocino, no por casualidad erigido en máximo galardón de las empresas bélicas y luego galantes del devenir cortesano de los Habsburgo.
} 
los Medici- creó unos modelos decorativos de la escena, que rememoraban tales elementos, propios de un medio natural salvaje, caótico e indómito, sobre el que, solamente, terminaba de imponerse el orden cósmico, por la intercesión de la acción cuasidivina, en el marco de la mentalidad humanística, del ser humano, aunque no de uno cualquiera, sino de aquél dotado de conocimientos y virtudes que le hacían merecedor de la cualidad del piloto que mejor podía hacerse con el gobierno de la nave del estado.

Así se plantea la escenografía en dos planos, como en los Intermezzi de Buontalenti, para separar dos niveles, el divino en la zona superior que simulaba el Olimpo de los dioses grecolatinos e igualmente útil por analogía para emplazar a los personajes regios, en este caso a Niquea, que fue encarnado por la infanta María, hermana de Felipe IV y, por otro lado el humano en la inferior, a nivel del suelo. Se componía esta última zona de decoración en forma de bosque, quizás en perspectiva, lo que no sería descabellado teniendo en consideración que Fontana se había formado en la cultura de una organización espacial ilusoria de una visión verosímil, en base a las demostraciones brunelleschianas. Pensamiento especulativo que fue codificado en una tratadística específica, formulada por Alberti, descrita como «ventana» a la que el espectador habría de asomarse, engañado por la técnica científica del artista, creyendo ver una ficción artificial prolongación del espacio real, todo lo cual fue luego descrito por Sebastiano Serlio, en su Segundo Libro de Arquitectura (1545) como «hábiles obras de perspectiva» aquellas propias que se realizaban para la escena teatral.

Tales prototipos escenográficos se pueden reconocer en las descripciones de los aparatos o «invenciones» o «ingenios» de la creación artística de Fontana, para la escenificación de la Gloria de Niquea ${ }^{11}$, la ninfa que se deshacía del maleficio de brujo

11 Parece probable que la infanta María, quien encarnó a Niquea, con el permiso de la reina Isabel, emulara a otra María, quien fuera reina de Hungría, una de las hermanas del emperador Carlos V, bajo cuyos auspicios se creó el montaje denominado como «torneo temático o de invención», reformulación de los medievales Pasos de Armas, para las fiestas de Binche, donde residía ya viuda (donde ella misma participó como personificación de Fadada, fundada sobre el personaje a su vez de la Mafada que aparecía en la otra de las historias bien conocidas de la literatura caballeresca, de Palmerín de Oliva de 1511 o en base a Urganda la Desconocida del Amadís), para agasajar a su sobrino en su presentación europea como heredero imperial, descrito por Calvete de la Estrella en su Felicisimo viaje (1552) y que se considera uno de los exponentes de la inauguración de la transformación del género caballeresco en espectáculo cortesano. Allí, quien fracasara a la postre en su empresa como emperador pero sí futuro rey de España, Felipe II, participó personalmente como protagonista de la escenificación, encarnando a Beltenebros, reencarnación a su vez de Amadís de Gaula, del héroe medieval de referencias artúricas que lograba vencer al mago Norabroch, de connotaciones negativas frente al modelo ético que representaba el vencedor de una trama que transcurrió en varias jornadas, por distintas dependencias de la hoy desaparecida residencia de la ex reina, para la que se improvisaron decoraciones efímeras de los distintos episodios narrados en una historia donde se mezclaban escenificaciones de pruebas del esfuerzo del príncipe, a la manera igualmente de lo que fueran no sólo pruebas físicas sino de valía moral de trasfondo mitológico, como las Doce de Hércules, el otro héroe de connotaciones clásicas cuyas peripecias confluían en el ideario publicitario que se estaba construyendo para respaldar la imagen del pretendiente al trono imperial. No en vano, el personaje semidivino, representativo de la propia nacionalidad griega, era uno de los dioses tutelares del emperador Carlos $\mathrm{V}$ y antes que él de su visionario abuelo paterno, Maximiliano de Austria, el verdadero codificador de la propaganda áulica imperial, pero, sobre todo quien, como soldado de fortuna al servicio de distintos señores italianos para mitigar su proverbial 
o hechicero, reformulación en masculino (Anaxtaranax) de la sempiterna Circe de los textos habituales de la literatura italiana. Se estaba configurando de esta forma a lo, protagonistas de los nuevos espectáculos, que venían a ser encarnación del mal, del salvajismo inherente al ser humano, sobre el que terminaba imponiéndose el héroe y por extensión su homólogo humano, o sea el monarca. Además, con el resto de parafernalia que también se creó para el evento, vinculada con el medio acuático (en este caso el cercano río fuente de riqueza del entorno hispano, o sea el Tajo) se revelaba a ojos de sus súbditos como el propio Neptuno, señor de las aguas primigenias, de la misma manera que tales embarcaciones artificiosas, rememorando las de las antiguas naumaquias romanas, se crearon en Florencia, incorporando el Arno ${ }^{12}$ como ámbito escénico nada aleatorio, porque formaba parte de la reivindicación ancestral de los gobernantes toscanos de Livorno como uno de sus puertos naturales para las confluencias con rutas comerciales y bélicas indispensables para la navegación por el Tirreno, como lo fue para los antiguos y originarios moradores de Etruria.

Alentando los pasos se abría una Montaña que cerraba en torno todo el Teatro y llegando a las columnas del encantado Palacio... nuestro Anfiteatro...dio lugar a una hermosa nube, que suspensa en los hombros del viento fue desatando sus dorados senos y abierta en cuadradas hojas bajó esparciendo lluvias de oro, como si viniera en ella transformado Júpiter...llegó a la puerta que sustentaban cuatro columnas, habiéndose con maravilloso artificio abierto la verde montaña, que cubría la máquina del Palacio...cerrose la Montaña y cubriose el Teatro y en tanto que los músicos cantaban el soneto de la segunda escena, se volvió a dividir el monte, y apareció en lo superior del Trono un jardín ... ${ }^{13}$

No obstante, el protagonista del escenario como elemento primordial era un monte, seccionado por su mitad, descrito con forma cóncava, habilitado para ambientar la imprescindible escena infernal, vinculada con el elemento ígneo, por un lado, en su aspecto subterráneo y es imposible no reconocer en este elemento el primer esbozo realizado por Leonardo en su faceta de director artístico de los montajes para

pobreza, había conocido de primera mano los usos y costumbres que se estaban imponiendo en I talia en el temprano Renacimiento artístico y cuyas «tácticas» plásticas importó a su propio terreno, ejemplo de lo cual se puede ver en la empresa de su Arco, realizado en forma de estampas reunidas para desplegar cada vez que hiciera una Entrada de connotaciones triunfales similares a las de antiguos emperadores romanos. Roy Strong, Arte y poder. Fiestas del renacimiento 1450-1650, (Madrid: Alianza Editorial, 1988). Y excepcionales análisis en el trabajo de Alberto del Rio Nogueras, "Motivos folclóricos y espectáculo caballeresco: el Príncipe Felipe en las Fiestas de Binche en 1549", Revista de Política Medieval 26 (2012), 285-302.

12 Paola Ventrone, "L'Arno come luogo teatrale fra Medioevo e Rinascimento", en Arturo Calzona e Daniella Lamberini, La civiltà delle acque tra Medioevo e Rinascimento, Atti del Convegno Internażionale Mantua 1-4 octubre 2008, II, vol. I,4 (Florencia: Centro di Studi L. B. Alberti, Ingenium, 2008), 589-611.

${ }^{13}$ Descripciones tomadas de distintos fragmentos del ejemplar conservado en la Universidad de Santiago de Compostela, localizado a través del portal de Archivos en red (PARES), del Ministerio de Cultura de España, de la Comedia de La Gloria de Niquea y descripción de Aranjuez por Juan de Tassis, impreso en Madrid por Diego Díaz de la Carrera (1643), 24-54. https://bvpb.mcu.es/es/consulta/registro.do?id=438982 
Ludovico el Moro en Milán, en las dos últimas décadas del siglo XV. Apenas unos garabatos en uno de sus cuadernos, junto a otros dibujos que hacen presumir los conocimientos que el genial artista tenía del Ingenio de San Felice de Brunelleschi, que parecen ser también los «instrumentos básicos» de la codificación de Buontalenti en la creación del entramado escenotécnico para los interludios musicales, que tampoco eran algo nuevo en Florencia y que ya formaban parte de una tradición previa, de un «poso» ensayado anteriormente en tiempos de Vasari para configurar el «cuerpo escénico». La forma en la que terminó siendo expresión explícita de la «Boca (o cierre) de Proscenio», a manera de mascarón infernal, repetida a lo largo de toda la escenografía del siglo XVII, se articuló, de nuevo, de manos de la gran figura, del gran capo de la fiesta medicea, erigida en poderoso «instrumentum regni», que fue Giulio Parigi y una de cuyas imágenes identitarias de toda la escenografía barroca representa la realizada por Lodovico Ottavio Burnacini, para las celebraciones del matrimonio del emperador Leopoldo con la infanta española Margarita Teresa, en el Teatro Auf der Cortina, en Viena (1668), para el montaje de Il Pomo d'Oro, libreto y grabados de los que se encuentran magníficos ejemplares en la Biblioteca Nacional de España (BNE). El otro espacio focal del escenario aludía al espacio palatino básico para ubicar el palacio o «regia» tomando como modelo el primigenio edificio que albergó a los Reyes de la Roma arcaica en el Foro y que tenía carácter sacro, de manera que la tipografía aludía, desde su creación, al carácter mayestático. Y, en el desarrollo de lo que fueron las denominadas «tramoyas» o maquinaria, también conocidas como vuelos o nubes, en este caso para esconder el mencionado monte, en la zona superior, parecen reconocerse reminiscencias de otras tramoyas medievales, como la de los "Misterios", como el de Elche, cuya escenificación perdura y todavía se puede contemplar en nuestros días, casi en los mismos términos de su uso en el pasado.

Es evidente que Fontana traía la impronta italiana no sólo para la arquitectura teatral, entendida como «caja escénica», sino también para la configuración escenográfica, fundamentalmente florentina, que se unieron a lo que Tassis pudiera ver en su exilio de 1611 a 1615, donde él mismo se encargó de hacer pública su ofensa de no haber sido lo suficientemente agasajado por los señores de Toscana en su visita por aquellos lares. Chaves y otros tantos investigadores de espectáculo de los Habsburgo en España, sobre todo en la época de esplendor en el Buen Retiro, suelen mencionar modelos de referencia habituales no sólo de los de la fiesta en Aranjuez, sino de las creaciones de los florentinos que se hicieron cargo de los diseños para los montajes en tiempos de Felipe IV, Cosimo Lotti y Baccio del Bianco, obviando la referencia fundamental de quien fuera maestro de ambos y «valido cultural» plenipotenciario de la Florencia del primer cuarto del siglo XVII, época en la que, precisamente Villamediana pasó por allí y ese no fue otro que Giulio Parigi ${ }^{14}$.

\footnotetext{
${ }^{14}$ Fuentes para su conocimiento: Baldinucci, Tinghi y la temprana recuperación de su figura para la historiografía, los distintos trabajos de Blumenthal. Nacido en el seno de una familia originaria de Prato, era sobrino nieto de Bartolomeo Ammannati y se había formado en la senda de los modelos artísticos del Manierismo dionisíaco epatante de Giambologna y Pietro Tacca, también como discípulo de Bernardo Buontalenti, de quien heredó una buena parte de sus materiales de trabajo escenográfico, habiendo colaborado, incluso, en la organización de los Intermezzi de 1589. Su padre, Alfonso di Santi,
} 
Pese a la repetida denominación de anfiteatro, en una evidente evocación del mundo clásico, el edificio creado en Aranjuez no parece que reprodujera estrictamente la forma de la tipología romana, sino la reelaboración hecha en época moderna para la ubicación de los nuevos espectáculos cortesanos. Es cierto que analizando detenidamente sus medidas, la forma en planta se ajustaba más a la del anfiteatro o doble teatro romano a la manera vitruviana y menos a la forma de $\mathrm{U}$-reconoce Chaves Montoya- que terminaron teniendo los edificios teatrales que se fueron gestando en las cortes tardorrenacentistas italianas, que incluían multifunciones relacionadas con la representación, como el escenario propiamente junto a una prolongación del ámbito ante la escena en lo que antes era la orchestra, sobre todo para ampliar el movimiento coreografiado fuera del proscenio, de personas y carrozas en lo que se conocía como la tipología del carrusel o evolución cortesana del torneo medieval e incluyendo además los espacios de almacenes de vestuario, maquinaria y la gestión empresarial del espectáculo. Esta tipología edilicia quedó configurada en el gran salón de los Uffir̨i, que desde entonces centralizaba los espectáculos de la política cortesana de los Medici, diseñado por Bernardo Buontalenti, si bien quien le dio la máxima utilidad beneficiándose del diseño fue Giulio Parigi ${ }^{15}$. Pero no sólo parece ser éste el modelo de referencia de lo acaecido en Aranjuez sino también un híbrido derivado de la asentada vocación cívica florentina y dentro de ésta, las celebraciones oficiales ya se empezaron a multiplicar exponencialmente desde finales del siglo XIV, porque respondían a una necesidad e intención publicitaria con una magnitud «exagerada» ${ }^{16} \mathrm{y}$

conocido como Il Francia, había progresado en el entorno de Giorgio Vasari y a la muerte de éste en 1574 se habría hecho cargo de la edificación de los Uffizi, desde donde se centralizaba el aparato administrativo de los Medici.

${ }^{15}$ De todos quienes recogieron información sobre Parigi se deduce la misma conclusión, esto es, haberle dotado de entidad monumental a su trabajo como escenógrafo, produciendo montajes de enorme exuberancia y riqueza creativa, aunando en el resultado final todas las disciplinas que componían la fiesta de tradición medieval como danzas o tramoyas mistéricas, en el espectáculo integral barroco de gran utilidad para la propaganda política de quienes fueron sus mecenas, los Medici, especialmente ágiles en la utilización de todos los recursos plásticos en beneficio propio, primero de distinción de familia burguesa ya a estas alturas de la época moderna, erigidos en estirpe dinástica, como el resto de monarquías europeas y a quienes el artista debía su propia formación. Con tan solo una veintena de montajes, entre 1608 y 1625, que incluían producción, ambientación y colaboración estrecha con autores de los textos y de la música, logró fama, una posición de prestigio y considerable fortuna, además de su nombramiento como arquitecto granducal, a la manera de lo que se podría considerar precedente del cargo de superintendente de las propiedades de los Medici, con el privilegio de acceso a las estancias particulares de sus mecenas, fundamentalmente Cosimo II y educación de los infantes, miembros de la nobleza y artistas vinculados a la corte medicea, en la Academia, heredada de Buontalenti, en una vivienda de la via Maggio, muy próxima al Palacio Pitti y a su propia residencia particular.

16 André Chastel, Arte y bumanismo en Florencia en tiempos de Lorenzo el Magnifico, Arte y bumanismo en Florencia en tiempos de Lorenzo el Magnífico (Madrid: Ediciones Cátedra, 1982), 194-195. Se recoge información sobre el impulso dado por Lorenzo a la preparación de, entre otros, canciones para Carnaval. En los desfiles de las carrozas, que se articulaban a manera de los triunfos romanos, se empezaron a incluir cuadros históricos, que recreaban precisamente los de Pablo-Emilio, realizado en 1491 por Granacci y escenificación de cuadros vivos mitológicos, todo lo cual contribuyó a la gloria póstuma del personaje, luego rememorado por la organización de los espectáculos oficiales de mediados del siglo XVI, por Giorgio Vasari. En esas mismas fechas tempranas ya se hacía mención de la 
fundamentalmente porque «las novedades de la cultura se desplegaban allí en el marco de las tradiciones locales». A partir del siglo XV, Florencia inauguró una tipología festiva de las que no había apenas equivalente en otras partes, ni de Italia ni en el resto del mundo. La misma ciudad se convirtió en un escenario, en cuyo entramado urbano se fueron consolidando espacios permanentes, a partir de una tradición remota que se remontaba a sus orígenes romanos, «recuperados» para la celebración política aunque aparentemente improvisados con carácter provisional. Es el caso de las piazzas, fundamentalmente Santa Croce pero igualmente otras no menos significativas, como la de Santa Maria Novella o el terreno en torno a la fachada del Palacio Pitti, ya en Oltrarno al otro lado del río, aprovechada de manera masiva para estos usos, una vez que la propiedad pasó a manos de los Medici.

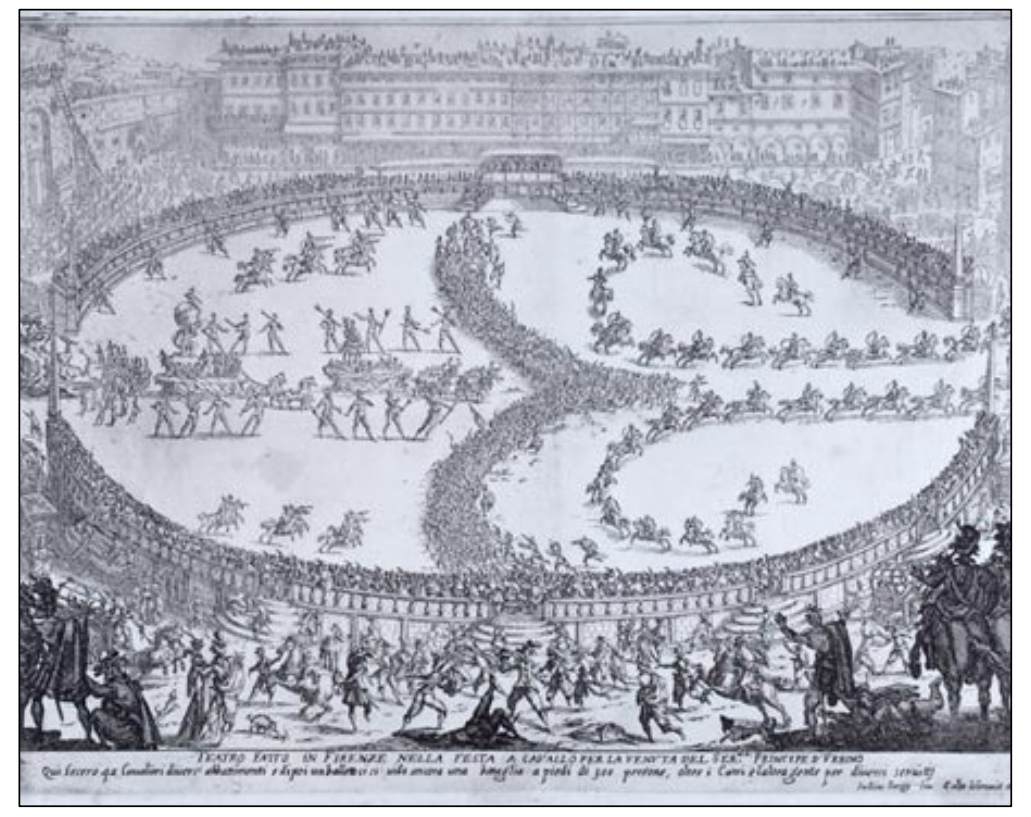

Fig. 2. Grabado de Jacques Callot, Guerra de la Belleza, Ballet ecuestre celebrado en la Piazza de Santa Croce, Florencia, para la recepción del Federico de Urbino, prometido de Claudia, hija de Cosme II, 1616, con el Carro del Sol, con decoraciones y carros ideados por Giulio Parigi, BNE.

importancia de la indumentaria, para la «vistosidad» del espectáculo, de forma que diseñadores y modistos se mostraban atentos a las modas borgoñonas, para incrementar la espectacularidad de las fiestas. 


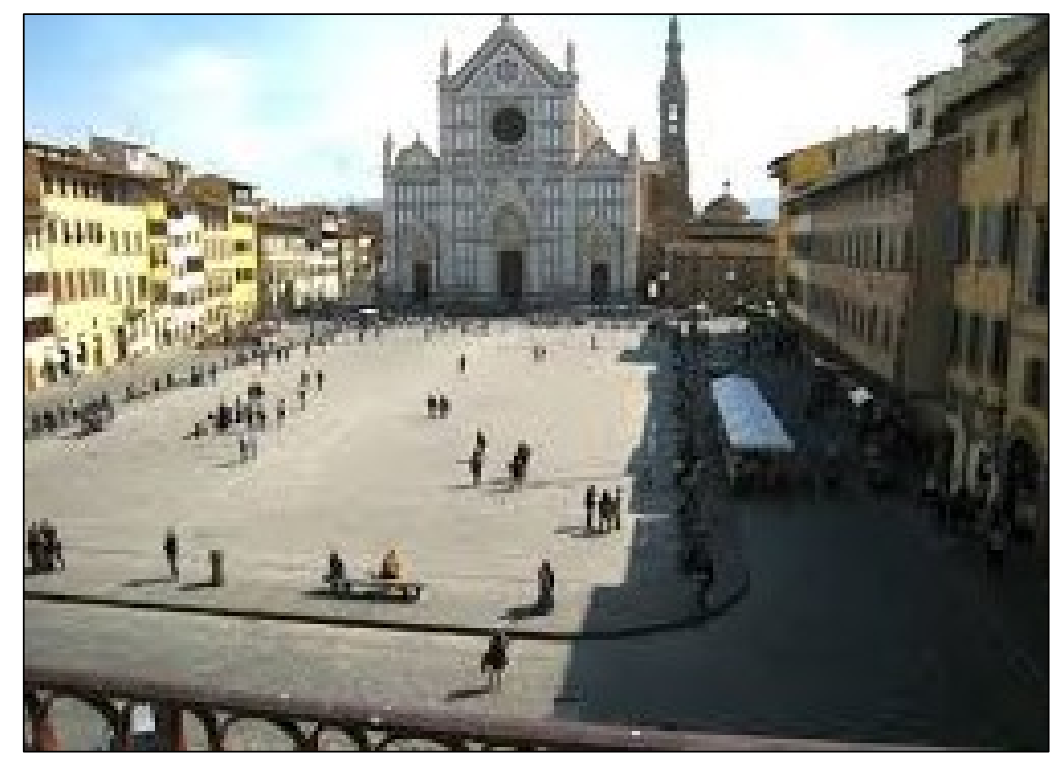

Fig. 3. Piazza de Santa Croce, Florencia.

Estos espacios de las plazas se erigieron en epicentro de la vida representativa habituales en el calendario festivo, pero lo que es más relevante si cabe, es su influencia en la conformación de un modelo arquitectónico como es el del edificio teatral, a manera de «coso» o coliseo, en el que, no se aludía únicamente a la planimetría estricta del Coliseo Flavio, cuya rotunda presencia era muestra no sólo de un edificio del pasado romano, sino de la misma identidad latina. Pero, de igual manera, en el crisol de búsqueda de una solución acorde con los nuevos usos y costumbres de la nueva sociedad cortesana, se tomaron como modelo de referencia otras tipologías arquitectónicas relacionadas con el espectáculo, como circos o estadios y ya en épocas tempranas aparecen soluciones como la del Belvedere en la sede pontificia de Roma, a comienzos del siglo XVI. Todo ello, por si fuera poco, impregnado, del mismo carácter apoteósico de la fórmula celebrativa romana del Triunfo, asociado a otra tipología arquitectónica, como era la de los Arcos, algunos de los cuales también seguían teniendo una imponente presencia en la ciudad que fue una de las principales capitales de la Antigüedad y que, con ese carácter, quisieron recuperarse del discurso retórico del pasado imperial, para insertarse en el nuevo vocabulario de la semántica constructiva teatral. Con esos mimbres se puede seguir el proceso de formación y su discurso teórico, en tratados como los de Francesco di Giorgio Martini, Fra Giocondo o Cesariano, de Sebastiano Serlio y Nicolò Sabbattini, imprescindibles por ejemplo en los primeros ensayos de Aleotti, para distintos teatros efímeros para otras tantas celebraciones en territorios de Emilia y en Parma, previos a la construcción del impresionante Teatro en el Palacio de la Pilotta, para los Farnese (1619). 
Cuando Villamediana ${ }^{17}$ pasó por Florencia, la actividad de Parigi $(1571-1635)^{18}$ estaba en pleno esplendor. Fue este personaje quien realmente se benefició de las investigaciones de sus predecesores Vasari y Buontalenti para crear el andamiaje del ideario político inserto en los espectáculos al servicio de sus patrones, los Medici del primer cuarto del siglo XVII (Cosme II y Ferdinando II), lo que le sirvió para situarse en el centro neurálgico de la vida social florentina, como «regista» o máximo regidor o director artístico, a manera de «factótum» de los entresijos sobre los que asentaba la política áulica, alcanzando de paso una posición acomodada nada desdeñable, incluso con acceso directo al ámbito privado del monarca que reinaba en el estratégico microuniverso toscano. A partir de lo acaecido en la Florencia de las primeras décadas del siglo XVII se creó el modelo exportado a otras cortes señoriales italianas primero y a las de los monarcas absolutistas del pleno Barroco, después, sin olvidar la confluencia de la presencia de Fontana que para el montaje de Aranjuez supone la importación del sistema italiano en la incorporación de la fórmula del entretenimiento como instrumento de gobierno o cauce de instrumentalización de las celebraciones lúdicas como forma de glorificación y propaganda.

La escenografía engloba muchas competencias que comparten conocimientos y criterios científicos, como fue el gran despliegue de la gran maquinaria barroca, que fue sustituyendo la genérica tramoya medieval, como la de los Misterios, o los ingenios o creaciones de la época moderna, en una franja en la que se mueven las creaciones de Brunelleschi, como la que servía para escenificar la Anunciación en las celebraciones religiosas de la Iglesia de San Felice in Piazza, en Florencia.

${ }^{17}$ Sin olvidar tampoco las más que ostensibles influencias derivadas, a su vez, de las «máscaras» británicas, institucionalizadas por Iñigo Jones y Ben Jonson, habituales en la corte de los Estuardo, donde estuvo el padre de Villamediana en distintas misiones diplomáticas.

${ }^{18}$ En castellano ver Merino, Esther y Eduardo Blázque Mateos, "Historia de la escenografía de la época moderna: Giulio Parigi. La Edad dorada de la escenografía florentina”, Divino escenario. Aproximaciones a la bistoria de las artes escénicas (Madrid: Ediciones Cumbres, 2014), 75-114. 
2. Escenarios efímeros e improvisados en el Alcázar. De E1 Nuevo Olimpo (1649) a Los celos hacen estrellas (1672).
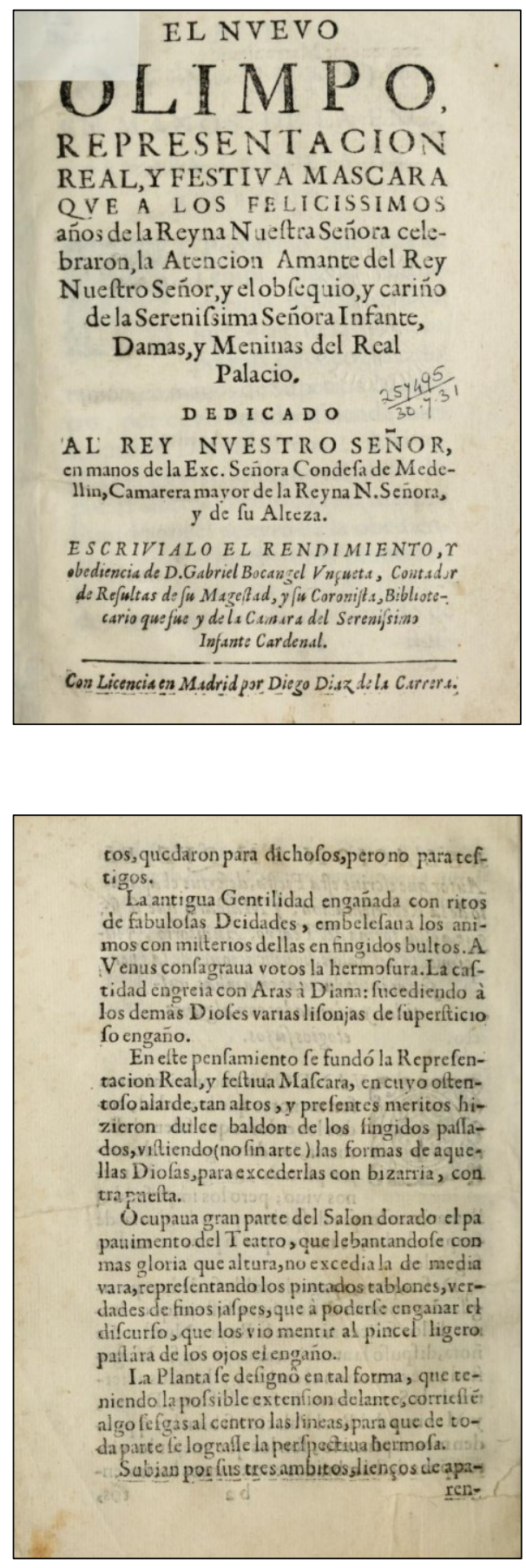

Figs. 4 y 5. Portada y Fragmento del texto del Nuevo Olimpo, donde se hace alusión a la planta y disposición del Teatro del Salón Dorado, en el Alcázar de Madrid. 
En el laberinto del antiguo Alcázar ${ }^{19}$, como en el resto de residencias palatinas de los Austrias, hasta la construcción del Coliseo del Buen Retiro en 1640 no había un emplazamiento fijo para las representaciones del entretenimiento cortesano. Lo más parecido, por su frecuencia habitual para estos usos, fue el Salón Dorado, donde precisamente se llevaron a cabo los trabajos para el montaje de la máscara del Nuevo Olimpo cuyo texto fue realizado por el genovés Gabriel Bocángel (1603-1658), para festejar el decimocuarto cumpleaños de quien sería la nueva esposa de Felipe IV y con ello una especie de mayoría núbil de Mariana de Austria (1634-1696), que llegó a España justo al año siguiente en 1649.

Con ese título ya se podían aventurar las intenciones laudatorias y panegíricas de una monarquía en decadencia que, sin embargo, intentaba emular y compararse con los dioses del universo olímpico de la mitología grecolatina, sancionado en la literatura homérica. Esa era la razón subyacente en un texto en que la principal protagonista fue la infanta María Teresa, denominada como Mente-Divina, en la que es imposible no reconocer las alusiones a la diosa de las armas y las letras, nacida de la mente de Júpiter, con quien, por tanto, se hacía la analogía del monarca hispano, que presidió la representación desde el centro de entramado artificial ${ }^{20}$ creado para su glorificación ante un selecto público, emplazado a los lados del sitial regio, en perpendicular con el escenario, que, según se señala en el texto, apenas levantaba del suelo medio metro y además, simulando mediante artificio ilusorio pintado, «finos jaspes».

En la corte española no existía la cultura de la perspectiva basada en la «ventana albertiana», de manera que para los entretenimientos se improvisaba lo que se conocían como «cuadros», con medios muy toscos, a la manera de los tableaux vivants, de tradición francoflamenca. Quizás esa fue la razón de que el rey Felipe II permitiera ese tipo de distracciones a su tercera esposa Isabel de Valois, para que se sintiera un tanto más cómoda de los rigores austeros que conllevaba la férrea etiqueta del monarca escurialense, más acostumbrada sin embargo a la relajación -aunque no carente de importancia política para mantener la coherencia en una corte tan escindida como la francesa- en los festejos que había impuesto allí su madre, Catalina de Medici. ${ }^{21}$

Con todo, la implantación de una nueva tradición cultural escénica empezaba a cobrar forma, precisamente a raíz de la reformulación de la literatura caballeresca

${ }^{19}$ F. Javier Bravo Ramón, "El Teatro en la Corte de los Austrias", Obras teatrales de carácter operístico del reinado de Felipe IV (Pontevedra: Editorial Academia del Hispanismo, 2015), 77-87.

20 Teresa Chaves Montoya, propone a Pedro Núñez del Valle y Francisco Rizi, como posibles autores del diseño escenográfico, en El espectáculo teatral en la corte de Felipe IV (Madrid: Ayuntamiento de Madrid- Área de Gobierno de las Artes, 2004), 145. Sobre este tema, ver también Trevor J. Dadson, $L a$ casa bocangeliana. Una familia hispano-genovesa en la España del Siglo de Oro, Eunsa (Pamplona: Ediciones de la Universidad de Navarra, 1991). $\mathrm{M}^{\mathrm{a}}$ Asunción Flórez Asensio, Teatro musical cortesano en Madrid durante el siglo XVII: espacios, intérpretes y obras (Madrid: Tesis Doctoral, Universidad Complutense de Madrid, 2004). Greer, Margaret R. y Varey, John E., El teatro palaciego en Madrid: 1586- 1707. Estudio y documentos (Madrid: Támesis, 1997). Neumeister, Sebastián, Mito clásico y ostentación: los dramas mitológicos de Calderón (Kassel: Edition Reichenberger, 2000). Varey, John E., «L'auditoire du Salón Dorado de l'Alcázar de Madrid au XVII e siècle», en Jean Jacquat (ed.), Dramaturgie et société. XVI et XVII siècles (París: Éditions du Centre National de la Recherche Scientifique, 1968), 77-91.

${ }^{21}$ Roy Strong, Arte y poder. Fiestas del Renacimiento 1450-1650 (Madrid: Alianza Editorial, 1988). 
como soporte de un renovado argumentario de los espectáculos señoriales. Como en Binche $^{22}$, pero ya en el siglo XVII, en el Alcázar se fueron improvisando espacios para los distintos episodios espectaculares, con ocasión de celebraciones especiales, pero también otros por el simple divertimento cortesano. Así la tarde-noche del 27 de julio de 1629, se ubicó la estructura efímera para la representación del Palmerín de Oliva en el Jardín de los Naranjos, que formaba parte a su vez del Jardín de la Reina y que «era habitual durante las canículas». También allí tuvo lugar, aunque cinco semanas después, el montaje de la Comedia de Merlín, diseñadas ambas probablemente por el florentino Cosimo Lotti. ${ }^{23}$ Por las distintas noticias sobre dicha representación (Tasaciones y datos/as de destajos del pagador Juan Gómez Mangas) se sabe que fue costoso, empleándose para ello 17.000 maravedís, entre otros por Alonso de Carbonel, como Aparejador Mayor de las Obras Reales y por Lotti, como Ingeniero. Al parecer se usó un artilugio formado de una cabeza de gran tamaño de serpiente o de dragón, como parte de una especie de máscara de dos piezas, que facilitaron la transformación rápida de la dicha sierpe, en mujer, a plena vista del público. Un segundo monstruo entró en la sala volando por los aires, de una parte a otra del escenario, en otro momento de la representación, gracias a un aparato que lo sujetaba mediante un sistema de grúa que se controlaba desde el interior de los espacios entre bastidores, cuya cabeza asemejaba la de otra serpiente, conocida en la tradición hispana de las celebraciones carnavalescas como «tarascas», que tenía la capacidad de simular el fuego por las fauces, con una pequeña silla de montar, que habría de simbolizar el control humano del «jinete» sobre la «fiera», sobre el monstruo prefiguración de las fuerzas desbocadas de la indómita naturaleza. El Secretario-Supervisor de lo que podría entenderse como «producción» como tan acertadamente denomina Peale, fue Tomás de Angulo, quien, además, hubo de emplearse a fondo para tener listo tan complicado entramado en veintitrés noches, contratando a varios vigilantes. En las «datas» o datos de las cuentas para el montaje del Palmerín, se mencionaban otros relevantes personajes del ámbito artístico cortesano, como el Veedor y el Maestro Mayor de las Obras Reales, Sebastián Hurtado y Juan Gómez de Mora, respectivamente, este último especialmente significativo, dada su implicación como supervisor de las obras del conjunto del Sitio del Palacio de El Buen Retiro ${ }^{24}$, donde, a la postre habría de construirse el Coliseo ${ }^{25}$, en el mismo corazón del entramado palatino, una sede estable para ubicar las representaciones cortesanas y en cuyas primeras representaciones escenográficas tuvo tanta vinculación el mismo Lotti, quien si bien no constaba en los papeles y documentación relativa al montaje del Palmerín como si lo hacía en la Comedia de Merlín junto a Juan de Baraona

22 Ibidem, 86-104.

${ }^{23}$ Otro excelente trabajo documental el que registra estas noticias, de C. George PEALE, "Sobre la fecha y la escenografía de Palmerín de Oliva, del Doctor Juan Pérez de Montalbán”, Revista Criticón 123 (2015), 167-191. Consulta on line. https://doi.org/10.4000/criticon.1571

${ }^{24}$ Jonathan Brown y John H. Elliott, Un palacio para el Rey: El Buen Retiro y la corte de Felipe IV, Libro electrónico, 2016.

${ }^{25}$ Juan P. Arregui, “Acerca del perspectivismo escenográfico y del teatro cortesano en la España de finales del siglo XVII y comienzos del XVIII”, Castilla: Estudios de Literatura 27 (2002), 31-62. 
y el pintor Angelo Nardi, es de buena lógica que fuera el responsable de la creación de las decoraciones.

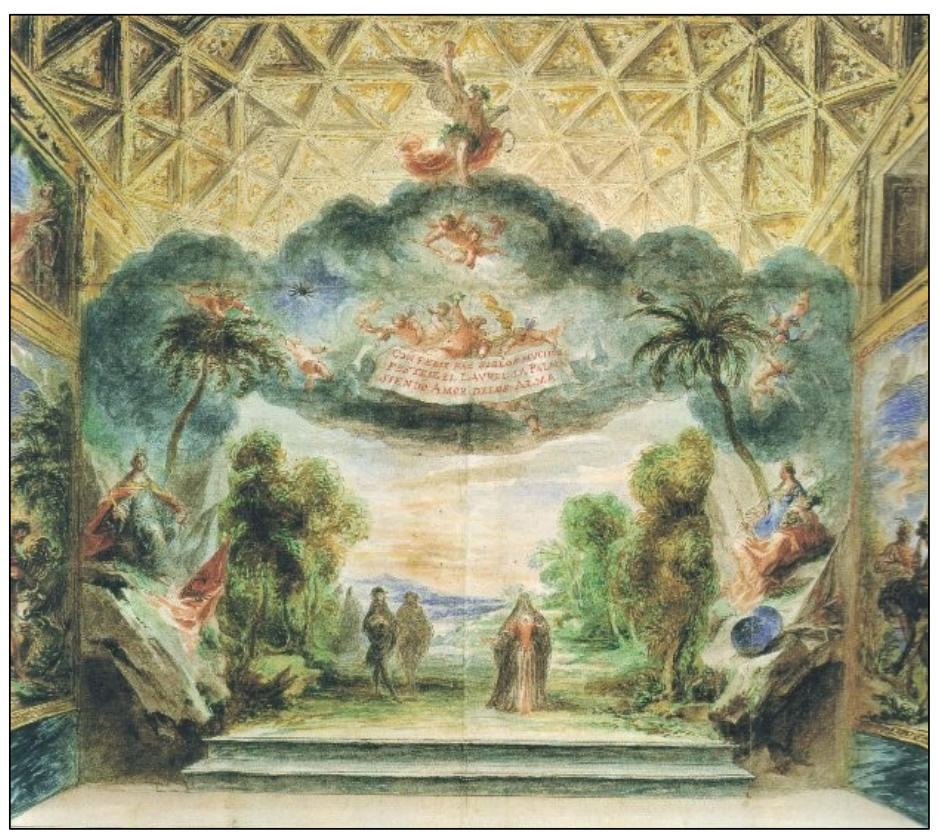

Fig. 6. Luis Vélez de Guevara, Los celos hacen estrellas. 1672. Acuarela de Francisco Herrera el Mozo, con la decoración del Salón Dorado en el Alcázar de Madrid. Perspectiva de la sierra de Guadarrama como fondo decorativo de la Loa. Viena, Österreichische Nationalbibliothek, Cod. 13.217

La comedia Los celos hacen estrellas ${ }^{26}$ se estrenó el 22 de diciembre de 1672, día de cumpleaños de la reina Mariana, como celebraba El Nuevo Olimpo tantos años antes, también en el Salón Dorado, una amplia estancia localizada en el ala sur de la vieja residencia real desde los remotos tiempos de los Trastámara, la cual había sufrido una serie de reformas parciales hasta la de 1640, fecha en que el artesonado del techo fue dorado y sus paramentos cubiertos con tapices y pinturas, entre ellos los tejidos historiados con la campaña de Túnez de Carlos $\mathrm{V}$ y los retratos de treinta y dos reyes de Castilla, colgados en la zona superior, frente a las ventanas que daban a la galería sur del patio interior del Alcázar. En este caso, se puede documentar con certeza la intervención del pintor sevillano Herrera el Mozo, tanto como autor de la escenografía para el montaje del texto de Vélez de Guevara y de las acuarelas para enviarse a la corte vienesa, con las que dar cuenta de la crónica oficial del festejo, casi más importante que la propia representación lúdica. Herrera se había formado en Roma junto a Pietro da Cortona y en la senda estilística de los denominados pintores quadraturistas, de manera que estaba versado en la práctica ilusionística de la creación de espacios

26 Teresa Chaves Montoya, “Asimilación y continuidad de la escenografía a la italiana en las fiestas teatrales del reinado de Carlos II”, en Alfonso Rodríguez G. de Ceballos y Ángel Rodríguez Rebollo, coords., Carlos II y el arte de su tiempo (Madrid: Fundación Universitaria Española, 2013), 445-484. 
fingidos ampliados hasta casi el infinito, dentro de un ámbito imperante rayano en lo que se puede definir como «cosmoobsesión perspectiva» de las artes plásticas.

La primera de las imágenes conservadas permite vislumbrar, además del artesonado dorado y parte de los tapices y pinturas que decoraban la estancia, la estructura habilitada para las representaciones teatrales, con un escenario apenas sobreelevado del suelo del recinto, al que se accedía mediante un par de escalones, que indican pocos cambios con respecto a la representación del montaje del Nuevo Olimpo, además de los dos o tres pares de bastidores laterales que parecen enlazar con las pinturas del salón a manera de cierre, de lo que sería una improvisación de la denominada Boca de Proscenio o embocadura de la parte externa del escenario, que se completaba con un telón que separaba todo el ámbito escénico de la zona habilitada para ubicar a los espectadores. Una innovación, que, sin embargo, ya venía contemplada en el diseño arquitectónico unitario del Coliseo en el Palacio de El Buen Retiro, como aportación vinculada a los modelos de influencia de procedencia italiana, ensayado de forma temprana en el Teatro Farnese de Parma, de Giambattista Aleotti, en las primeras décadas del siglo XVII, a partir de las reformulaciones del Teatro de los Uffizi de Buontalenti, el Teatro de Sabbioneta de Vincenzo Scamozzi y del Teatro Olímpico de Vicenza de Andrea Palladio.

\section{El Coliseo como plasmación de la influencia florentina e italiana en general}

Cosimo Lotti (c. 1575-1643) había llegado a España en junio de 1626. Había sido colaborador de Giulio Parigi en el trazado de los jardines de Boboli, donde habría diseñado fuentes, grutas, como también habría hecho para la Villa Reale de Castello, entre otros. Era bien conocido en Florencia como «ingeniero mecánico», así le había denominado Galileo, quien le consideraba un «buen amigo». Su trabajo más relevante antes de venir a España, fueron los diseños escenográficos de los cinco actos y seis Intermezzi para la Andrómeda de Jacopo Cicognini, fábula marítima, cuyo montaje se llevó a cabo en el Palacio della Gherardesca (1618).

Blumenthal ${ }^{27}$, el autor de la primera monografía exhaustiva de Giulio Parigi y que mantiene su vigencia historiográfica, recogía la idea apuntada por Baldinucci, principal fuente de datos biográficos de los artistas del siglo XVII (como lo fue Vasari en la centuria anterior), en el sentido de que cuando el rey Felipe IV pidió un escenógrafo al Gran Duque de Toscana, para que le organizara la producción de los espectáculos del Buen Retiro a la manera italiana, Parigi habría aprovechado la ocasión para librarse de un alumno brillante que empezaba a hacerle sombra, sobre todo en un momento en el que Parigi estaba en el esplendor de su carrera en el universo mediceo. En cualquier caso, parece haber coincidencia en que Lotti acogió con alegría el encargo, al menos al principio y su primer trabajo en la corte española fue el diseño escenográfico y maquinaria para La Selva sin amor de Lope de Vega en 1629.

${ }^{27}$ Arthur R. Blumenthal, "The influence of Parigi's stage design”, Giulio Parigi's stage designs. Florence and the Early Baroque Spectacle (Nueva York: Garland Publishing, 1986), 299-301. 
Las obras del Palacio del Buen Retiro comenzaron en 1633 y el Coliseo (para ubicar las representaciones teatrales palatinas, que antes se improvisaban en espacios no específicos) ${ }^{28}$, fue inaugurado en 1640 . De la arquitectura de la "caja" propiamente del teatro, algo más se conoce o noticias gráficas se tienen que de las decoraciones escenográficas, salvo algunas descripciones o información contenida en los libretos de los autores de los textos y de los creadores de los aparatos escénicos. Por eso son de especial relevancia los pocos testimonios conservados, siendo especialmente significativo que de Lotti -con quien se inaugura la presencia florentina en España con las creaciones para la ambientación decorativa de la Selva sin amor de Lope- no se conserven imágenes y haya que esperar a mediados del siglo XVII, con la llegada de Baccio del Bianco (1604-1657), procedente igualmente de Toscana, en sustitución de Lotti, para poder vislumbrar algo de lo que supuso la introducción de los modelos florentinos ya directamente, con las estampas de lo que fue el montaje de las Fortunas de Andrómeda y Perseo (1653) y ya después, a finales de la centuria, en 1698, para sendos telones de boca ${ }^{29}$, con los que empezaban las representaciones, en este caso a través de un dibujo de Francisco Ignacio Ruiz de la Iglesia ${ }^{30}$, de Ypodamia y Pelope, de Sebastián Rojas y otro de Antonio Palomino para la puesta en escena de Todo lo vence el amor, de Antonio Zamora.

Las valiosas imágenes muestran la influencia de los modelos iconográficos italianos de la escenografía apoteósica y desbordante de fin de siglo, fundamentalmente venecianos, de Burnacini, de Francesco Santurini o de Domenico y Gaspare Mauro. Pero, también de la fórmula que se fue imponiendo para la labor del escenógrafo, escindiéndose ${ }^{31}$ la antigua figura unitaria en un binomio de colaboración generalmente entre el arquitecto «tracista» del diseño global de la composición, a manera de ideólogo y el pintor de bastidores o telas de los decorados, quienes por sus conocimientos de las reglas de la perspectiva se consideraba que eran los más indicados para componer la decoración escénica a manera de construcción perspectiva realista y verosímil, aunque fueran, paradójicamente, estos artistas los que dieran la puntilla al sistema con

28 «Antes incluso de la construcción del Coliseo, la técnica escénica permitía, en la década de los treinta del siglo XVII, la presentación de trece cambios de escena en una obra de hora y media de duración, ya fuera en el Salón Dorado del Alcázar o en lo que hoy denominamos Casón», según recoge Carmen Sanz Ayan, «el discurso festejante de dos cortes en guerra. Las representaciones palaciegas en Madrid y Barcelona durante la Guerra de Sucesión», Revista D 'Historia Moderna 33 (2013), 229-266, 233.

${ }^{29}$ John. E. Varey, "Dos telones para el Coliseo de Buen Retiro", Revista del Ayuntamiento, Año XIX, 71(Madrid: 1981-II), 15-18.

30 Se alude a que Antonio Palomino y Francisco Ignacio Ruiz de la Iglesia eran por esas fechas, al final de la centuria, dos artistas consagrados en la capital de España. Este último, discípulo de Carreño había nacido en Madrid en 1649, desarrollando igualmente toda su actividad en la corte madrileña y al parecer conectó con Palomino desde el mismo momento en que se conocieron (mencionándose la casualidad de que la madre de Ruiz de la iglesia fuera igualmente cordobesa), cuando el de Bujalance llegó a Madrid, en 1678. Ver Teresa Zapata Fernández de la Hoz, "La Entrada de la reina María Ana de Neoburgo en Madrid (1690). Una decoración efímera de Palomino y de Ruiz de la Iglesia”, Anuario del Departamento de bistoria y Teoría del Arte (UAM), vols. IX-X (1997-1998), 257-275.

${ }^{31}$ Carmen González-Román, "El artista escenógrafo: una especialidad no reconocida en la Edad Moderna", 14 Congreso Nacional de Historia del Arte (CEHA) Correspondencia e integración de las artes, tomo I (Málaga: Universidad de Málaga, 2002), 207-223. 
ostensibles indicios de agotamiento, creando el sistema que suponía la ruptura de la visión monofocal, con la denominada «perspectiva angular», fundamentalmente de la mano de Ferdinando Galli Bibiena, el patriarca de la estirpe que luego imperara en la escenografía cortesana europea del siglo XVIII casi de forma hegemónica. Quizás, eso explicaría la forma de trabajo en la corte española, de la misma manera que serviría para entender la presencia en bibliotecas tan relevantes como la del arquitecto Teodoro Ardemans, del ejemplar de una de las obras más significativas de la tratadística escenográfica del siglo XVII, de Nicolo Sabbattini, recopilatorio a su vez de los conocimientos enumerados por Sebastiano Serlio y la experiencia práctica en el tema de Giacomo Torelli.

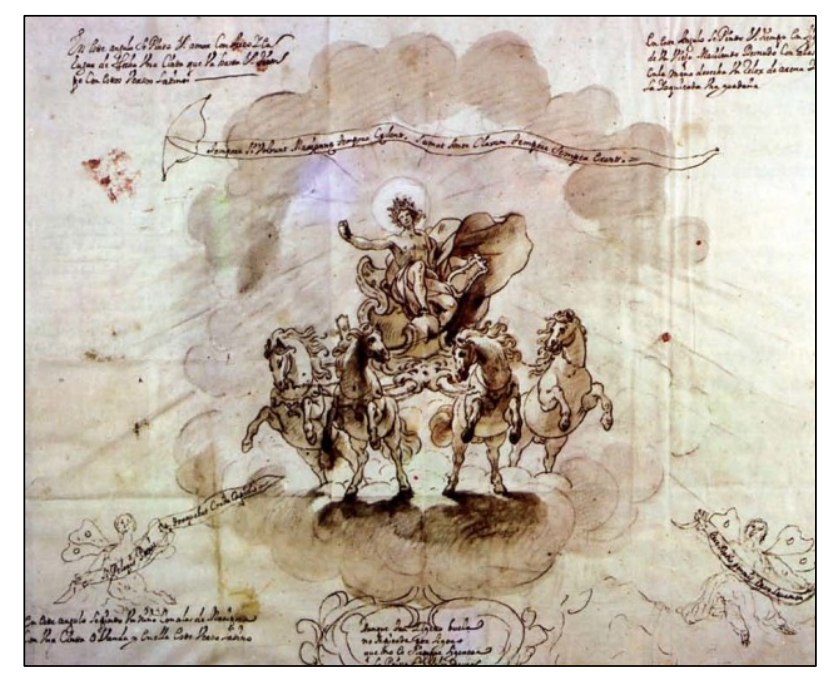

Fig. 7. Dibujo de Francisco Ignacio Ruiz de la Iglesia, para el telón de boca de la representación de Ypodamia y Pelope de Sebastián Rojas.

Baccio llegó a Madrid en 1651, entablando contacto en su juventud con Parigi, a través de su padre, quien trabajó a sus órdenes en el campo del vestuario, logrando así el cauce propicio para entrar en la famosa Academia de via Maggio (muy próxima a la residencia del Palazzo Pitti) donde se educaban los jóvenes de la corte medicea y donde permaneció entre 1614 y 1620. Después pasó un tiempo como arquitecto militar en Austria y Bohemia durante una década, completando su formación como discípulo del brillante Stefano della Bella, (quien sucedió a Parigi en las labores de organización de los festejos florentinos junto al hijo, Alfonso Parigi con quien organizó en 1637 el apoteósico montaje de Le nozze degli Dèr) y como prolífico grabador, a manera de cronista gráfico, como lo fue Jacques Callot para Giulio. Como su maestro, autor precisamente de la remodelación del anfiteatro ajardinado "di verzura" en el Palazzo Pitti, Baccio se había educado en la concepción arquitectónica consolidada para ubicar los espectáculos del entretenimiento cortesano, que fue la que se terminó por imponer en Europa y también en España, aunque influida en cierta medida por la práctica del teatro popular de los Corrales de Comedias, a la que los Austrias hispanos -sobre todo 
el rey Felipe IV- eran tan aficionados. Sin embargo, la temática imperante de los grandes asuntos mitológicos, con los que las monarquías del Absolutismo Barroco, pretendían identificarse a ojos de sus súbditos, como prerrogativa estamental, ya hacía necesarios otros usos y costumbres mucho más ampulosos a la hora de la puesta en escena, aunque fuera sólo por la utilización de una maquinaria escénica de grandes dimensiones, que impusieron cambios estructurales opuestos a las sencillas fórmulas del teatro popular, más asentado en la personalidad de los caracteres de los protagonistas de las tramas ideadas por los autores del Siglo de Oro.

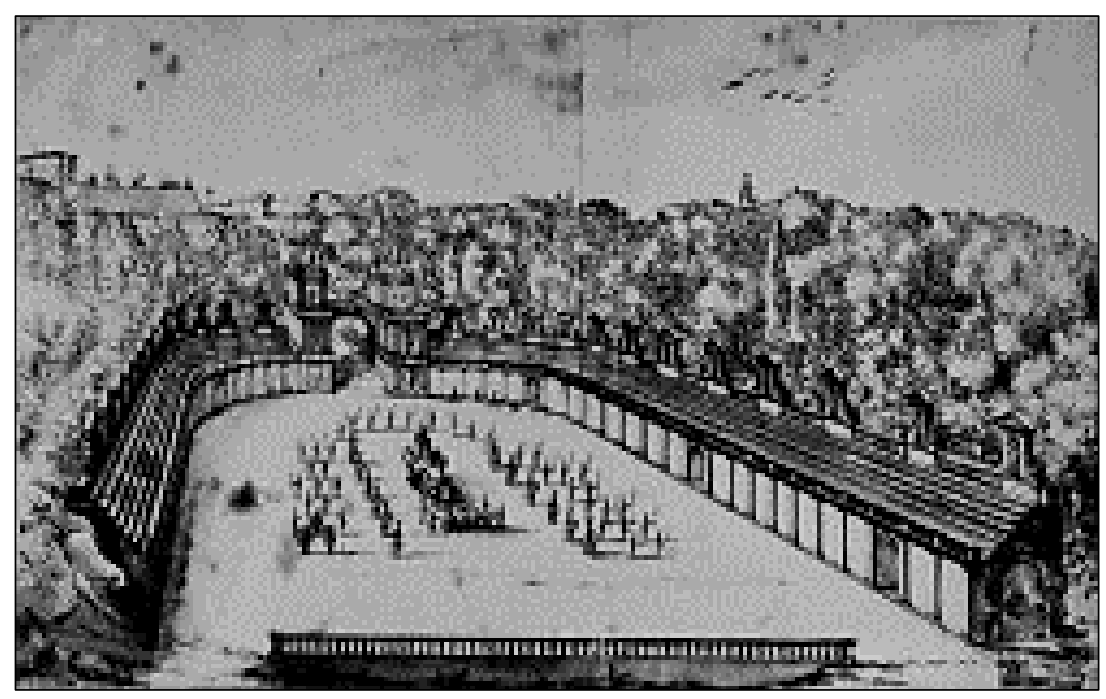

Fig. 8. Baccio del Bianco, Veduta dell'anfiteatro di Boboli con duplice figurazione coreográfica, 1637, Uffizi.

En definitiva, parece evidente que los modelos de influencia de la arquitectura teatral palatina, del Coliseo, proceden de la península vecina, pero más concretamente de Florencia -con la que existían estrechos vínculos y excelentes relaciones diplomáticas-, a partir de la codificación del protocolo de la lúdica áulica realizada por Giulio Parigi, quien encarna la figura de escenógrafo cortesano por excelencia, al artista total, por su capacidad para solucionar todas las necesidades de la propaganda al servicio de los Medici, gracias a lo que se configura el ideario del Absolutismo y cuyo modelo se exportó al resto de estados señoriales italianos y monarquías europeas. 


\section{REFERENCIAS BIBLIOGRÁFICAS}

Aguilar Perdomo, María del Rosario, "La disposición escénica: algunas arquitecturas efímeras de los libros de caballerías españoles", Revista Destiempos 23 (diciembre 2009-enero 2010).

Arregui, Juan P., “Acerca del perspectivismo escenográfico y del teatro cortesano en la España de finales del siglo XVII y comienzos del XVIII”, Castilla: Estudios de Literatura 27 (2002), 31-62.

Bianconi, Lorenzo, "Il libretto d'opera", en Il contributo italiano alla storia del pensiero (Roma: Istituto dello Enciclopedia Italiana Fondata da Giovanni Treccani, 2018), 187-204.

Blumenthal, Arthur R, “The influence of Parigi's stage design”, Giulio Parigi's stage designs. Florence and the Early Baroque Spectacle (Nueva York: Garland Publishing, 1986), 299-301.

Brown, Jonathan y John H. Elliott, Un palacio para el Rey: El Buen Retiro y la corte de Felipe IV, Libro electrónico, 2016.

Bravo Ramón, F. Javier, "El Teatro en la Corte de los Austrias", Obras teatrales de carácter operístico del reinado de Felipe IV (Pontevedra: Editorial Academia del Hispanismo, 2015), 77-87.

Cruciani, Fabrizio, Il teatro del Campidoglio e le feste romane del 1513 (Milán: Il Polifilo, 1968).

Chastel, André, Arte y bumanismo en Florencia en tiempos de Lorenzo el Magnífico (Madrid: Ediciones Cátedra, 1982).

Chaves Montoya, Teresa, La Gloria de Niquea. Una invención en la Corte de Felipe IV, Colección Riada, Estudios sobre Aranjuez 2 (Aranjuez: Editorial Doce Calles, 1991).

Chaves Montoya, Teresa, "Asimilación y continuidad de la escenografía a la italiana en las fiestas teatrales del reinado de Carlos II", en Alfonso Rodríguez G. de Ceballos y Ángel Rodríguez Rebollo, coords., Carlos II y el arte de su tiempo (Madrid: Fundación Universitaria Española, 2013), 445-484.

Dadson, Trevor J., La casa bocangeliana. Una familia hispano-genovesa en la España del Siglo de Oro, Eunsa (Pamplona: Ediciones de la Universidad de Navarra, 1991). 
Del Rio Nogueras, Alberto, "Motivos folclóricos y espectáculo caballeresco: el Príncipe Felipe en las Fiestas de Binche en 1549", Revista de Politica Medieval 26 (2012), 285-302.

Fagiolo, Marcello, La Città effimera e l'universo artificiale del giardino: la Firenze dei Medici e l'Italia del '500 (Roma: Officina Edizione, 1980).

Fagiolo, Marcello y Giuseppe BONACORSO, Studi sui Fontana. Una dinastía di architetti ticinesi a Roma tra Manierismo e Barocco (Roma: Centro di Studi sulla Cultura e l'immagine di Roma, Ministero per I Beni e le Attività Culturali, Gangemi Editore, 2016), 119.

Ferrer Valls, Teresa, "Teatros cortesanos anteriores a la construcción del Coliseo del Buen Retiro", Quaderns de Filología. Estudis literans, Edición en homenaje a la profesora Amelia García-Valdecasas, I (1995), 355-372.

Flórez Asensio, $\mathrm{M}^{\mathrm{a}}$ Asunción, Teatro musical cortesano en Madrid durante el siglo XVII: espacios, intérpretes y obras (Madrid: Tesis Doctoral, Universidad Complutense de Madrid, 2004).

González-Román, Carmen, "El artista escenógrafo: una especialidad no reconocida en la Edad Moderna", 14 Congreso Nacional de Historia del Arte (CEHA) Correspondencia e integración de las artes, tomo I (Málaga: Universidad de Málaga, 2002), 207-223.

Greer, Margaret R. y John E. VAREY, El teatro palaciego en Madrid: 1586- 1707. Estudio y documentos (Madrid: Támesis, 1997).

Merino, Esther, "De la guerra al espectáculo cortesano: El arte efímero en el torneo", en El reino de la ilusión. Breve bistoria y tipos de espectáculo. El arte efimero y los orígenes de la escenografía, Monografías de Arquitectura 01 (2005), 15-44.

Merino, Esther y Eduardo BLÁZQUEZ MATEOS, "Historia de la escenografía de la época moderna: Giulio Parigi. La Edad dorada de la escenografía florentina", Divino escenario. Aproximaciones a la historia de las artes escénicas (Madrid: Ediciones Cumbres, 2014), 75-114.

Neumeister, Sebastián, Mito clásico y ostentación: los dramas mitológicos de Calderón (Kassel: Edition Reichenberger, 2000).

Sanz Ayan, Carmen, "El discurso festejante de dos cortes en guerra. Las representaciones palaciegas en Madrid y Barcelona durante la Guerra de Sucesión”, Revista D’Historia Moderna 33 (2013), 229-266, 233. 
Strong, Roy, Arte y poder. Fiestas del Renacimiento 1450-1650 (Madrid: Alianza Editorial, 1988).

Varey, John E., «L'auditoire du Salón Dorado de l'Alcázar de Madrid au XVII e siècle», en Jean JACQUOT (ed.), Dramaturgie et société. XVI et XVII siècles (París: Éditions du Centre National de la Recherche Scientifique, 1968), 77-91.

Varey, John E., "Dos telones para el Coliseo de Buen Retiro", Revista del Ayuntamiento, Año XIX, 71(Madrid: 1981-II), 15-18.

Ventrone, Paola, "L'Arno come luogo teatrale fra Medioevo e Rinascimento", en Arturo Calzona e Daniella Lamberini, La civiltà delle acque tra Medioevo e Rinascimento, Atti del Convegno Internazionale Mantua 1-4 octubre 2008, II, vol. I,4 (Florencia: Centro di Studi L. B. Alberti, Ingenium, 2008) 589-611.

Zapata Fernández de la Hoz, Teresa, "La Entrada de la reina María Ana de Neoburgo en Madrid (1690). Una decoración efímera de Palomino y de Ruiz de la Iglesia", Anuario del Departamento de historia y Teoría del Arte (UAM), vols. IX-X (19971998), 257-275.

Recibido: 17 de septiembre de 2020

Aprobado: 22 de octubre de 2020 